Article

\title{
Effect of Agraz (Vaccinium meridionale Swartz) on High-Density Lipoprotein Function and Inflammation in Women with Metabolic Syndrome
}

\author{
Catalina Marín-Echeverri ${ }^{1}$, Christopher N. Blesso ${ }^{2} \mathbb{D}$, Maria Luz Fernández ${ }^{2} \mathbb{D}$, \\ Yeisson Galvis-Pérez ${ }^{1}{ }^{\mathbb{D}}$, Gelmy Ciro-Gómez ${ }^{1}$, Vitelbina Núñez-Rangel ${ }^{1}$, Juan C. Aristizábal ${ }^{3} \mathbb{D}$ \\ and Jacqueline Barona-Acevedo $1, *$ (D) \\ 1 Food and therapeutic alternatives area, Ophidism Program, School of Microbiology, \\ Universidad de Antioquia UdeA, Calle 70 No. 52-21, Medellín 050010, Colombia; \\ catalina.marin@udea.edu.co (C.M.-E.); yeisson.galvis@udea.edu.co (Y.G.-P.); \\ gelmy.ciro@udea.edu.co (G.C.-G.); vitelbina.nunez@udea.edu.co (V.N.-R.) \\ 2 Department of Nutritional Sciences, University of Connecticut, Storrs, CT 06269, USA; \\ christopher.blesso@uconn.edu (C.N.B.); maria-luz.fernandez@uconn.edu (M.L.F.) \\ 3 Research Group of Physiology and Biochemistry (PHYSIS), School of Nutrition and Dietetics, \\ Universidad de Antioquia UdeA. Calle 70 No. 52-21, Medellín 050010, Colombia; \\ juan.aristizabal@udea.edu.co \\ * Correspondence: maria.barona@udea.edu.co; Tel.: +57-421-965-36
}

Received: 24 October 2018; Accepted: 4 December 2018; Published: 8 December 2018

check for updates

\begin{abstract}
Metabolic syndrome (MetS) is associated with low-grade inflammation and high-density lipoprotein (HDL) dysfunction. Polyphenol-rich foods may improve these alterations. Agraz is a fruit rich in polyphenols (mainly anthocyanins); however, there is limited information about its effects on human health. We evaluated the effects of agraz consumption as compared to placebo on HDL function and inflammation in women with MetS. Forty volunteers (25-60 years) were included in this double-blind crossover study. Women consumed agraz or placebo over 4 weeks; separated by a 4-week washout period. HDL function (apoliprotein-A1; paraoxonase 1 (PON1) activity; cholesterol efflux capacity), oxidative stress (myeloperoxidase (MPO), advanced oxidation protein products) and inflammatory markers (serum cytokines/chemokines and peripheral blood mononuclear cell nuclear factor-kB) were measured after each period. Compared to placebo, agraz consumption did not significantly change any of the biomarkers measured. Interestingly, only after agraz period there were significant positive correlations between PON1 activities and cholesterol efflux. Additionally, there were significant inverse correlations between changes in inflammatory markers and HDL function markers and positive correlations with oxidative markers. Although polyphenol-rich foods have been shown to be beneficial for certain conditions; polyphenol-rich agraz fruit consumption did not impact inflammation and HDL function in the current study of women with MetS.
\end{abstract}

Keywords: Andean berry; cardiovascular risk factors; HDL dysfunction; inflammation; oxidative stress

\section{Introduction}

Metabolic syndrome (MetS) is a cluster of metabolic disorders shown to raise the risk of developing atherosclerotic cardiovascular diseases (CVDs) [1], which represent the leading cause of death worldwide [2]. This syndrome is associated with low-grade chronic inflammation characterized by increased C-reactive protein (CRP) [3], cytokines such as interleukin (IL)-6, tumor necrosis factor- $\alpha$ (TNF- $\alpha$ ) [4], monocyte chemoattractant protein-1 (MCP-1) [5], and IL-8 [6], supporting the evidence that inflammation plays an important role in cardiovascular risk. 
In addition, low high-density lipoprotein cholesterol (HDL-c) is another important component of MetS which is independently and inversely associated with cardiovascular risk [7]. However, this association seems to be complex given that high/normal HDL-c levels have been observed in people with CVD [8,9]. Disappointing results with drug therapies aiming to increase HDL-c have been reported, as some studies have not shown to prevent future cardiovascular events with increases in HDL-c $[10,11]$. This information suggests that other aspects of HDL should be considered.

Independently of the HDL-c level, HDL particles have shown atheroprotective roles through different functions such as reverse cholesterol transport [12], as well as anti-inflammatory [13] and anti-oxidant [14] activities. In chronic inflammatory states like MetS, dysfunctional HDL has been observed [15], characterized by low cholesterol efflux [16] and depletion of HDL-associated atheroprotective proteins including apolipoprotein A-1 (apoA-1) [17] and paraoxonase 1 (PON1), which are involved in cholesterol efflux [18,19], and antioxidant $[20,21]$ and anti-inflammatory properties [22,23]. Likewise, myeloperoxidase (MPO), a protein able to induce oxidative modification in HDL [24] and low-density lipoproteins (LDL) [25], has been found significantly elevated in people with MetS [26]. Similarly, advanced oxidation protein products (AOPP), formed mainly from oxidation with hypochlorous acid (HOCL), generated by MPO [27], has been associated with MetS [28].

Improvements in HDL functionality are being considered and could be more effective approaches to ameliorate CVD risk. For example, several clinical studies have shown that consumption of flavonoids influence HDL functionality, through increases in HDL-c levels [29], PON1 activity [30,31], serum cholesterol efflux capacity [29,31], HDL antioxidant capacity, and reduction of HDL lipid hydroperoxides [31]. These antioxidant compounds have also shown to inhibit the activation of nuclear factor kappa B (NF-kB) - an important transcription factor that regulates inflammatory responses [32,33].

Agraz (Vaccinium meridionale Swartz) is a fruit rich in flavonoids mainly anthocyanins which grows in Colombia as a wild berry. This fruit has shown high antioxidant activity [34] and ex vivo cardioprotective effect [35], which have aroused interest for its potential health benefits. However, currently there are limited published studies evaluating the effects of this berry in human health. We assessed the effects of agraz consumption, compared to placebo, on HDL function and inflammation markers in women with MetS. We hypothesized that agraz consumption, compared to placebo, would improve HDL function and decrease inflammation in this group of women.

\section{Materials and Methods}

\subsection{Study Population}

Forty women ( $n=40 ; 25-60$ years) with MetS, according to National Cholesterol Education Program (NCEP) Adult Treatment Panel III (ATP-III) guidelines [36] were recruited from Medellin-Colombia. MetS was defined as the presence of three or more of the following risk factors: waist circumference $\geq 88 \mathrm{~cm}$, triglycerides $\geq 150 \mathrm{mg} / \mathrm{dL}$, HDL-c $<50 \mathrm{mg} / \mathrm{dL}$, blood pressure $\geq 130 / \geq 85 \mathrm{mmHg}$, and fasting plasma glucose $\geq 100 \mathrm{mg} / \mathrm{dL}$ [36]. Those who had kidney disease, heart disease, diabetes, triglycerides $\geq 500 \mathrm{mg} / \mathrm{dL}$, fasting plasma glucose $\geq 126 \mathrm{mg} / \mathrm{dL}$, LDL cholesterol $\geq 190 \mathrm{mg} / \mathrm{dL}$, blood pressure $>140 / 90 \mathrm{~mm} \mathrm{Hg}$, consumed anti-inflammatory, lipid-lowering, hypoglycemic, and/or anti-hypertensive medications, consumed more than $20 \mathrm{~g}$ alcohol per day, smoked, were pregnant or planning to become pregnant, were high performance athletes, and/or consumed supplements or nutraceuticals, were excluded. This study was approved by the Human Bioethics Committee of the Sede de Investigación Universitaria, Universidad de Antioquia (Act No. 15-35-558-02). All participants signed the informed consent format.

\subsection{Experimental Design}

A double-blind study with a crossover design for 12 weeks was carried out. The volunteers were assigned to consume daily either agraz or placebo over 4 weeks, after which participants had a 4-week washout period, then they were allocated to the alternate treatment for additional 4 weeks (Figure 1). 
Freeze-dried agraz was reconstituted in $200 \mathrm{~mL}$ of water. The daily agraz dose was equivalent to the total phenols present in $200 \mathrm{~g}$ of fresh agraz (1027.97 $\pm 41.99 \mathrm{mg}$ gallic acid equivalents (GAE)/L of agraz beverage). Placebo was designed to match the agraz beverage in terms of look, feel, taste, and macronutrients but without any polyphenols. The physico-chemical characterization, antioxidant capacity, total phenols and anthocyanin composition of agraz and placebo used in this study has been previously described [37]. During the whole study, including the washout period, volunteers were asked to abstain from consuming polyphenol-rich foods such as grapes, other berries, wine and tea or derived products. Participants registered daily consumption of the beverages, and a weekly questionnaire to assess adherence to the study to ensure they drank the beverages as indicated. When compliance was lower than $80 \%$, participants were withdrawn from the study. Additionally, participants filled out a 7-day physical activity record and a food frequency questionnaire [38] at the beginning and end of each period to verify no changes in diet or exercise. Blood samples and data collection were obtained at the end of each consumption period.

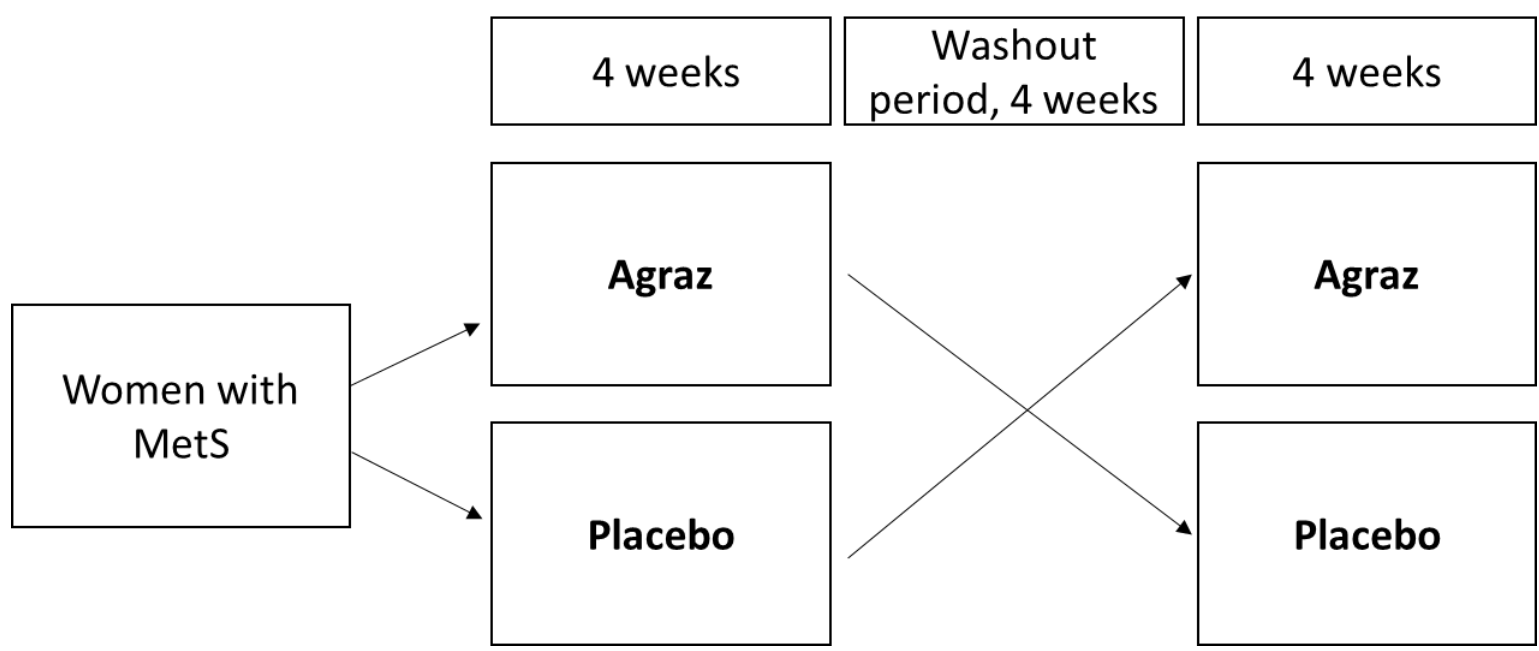

Figure 1. Study protocol. Women consumed agraz and placebo in a crossover design during 12 weeks (including a washout period). MetS: metabolic syndrome.

\subsection{Blood Collection and Peripheral Blood Mononuclear Cell (PBMC) Isolation}

Blood samples were obtained after a 12-h overnight fast, from the antecubital vein using serum separator tube (yellow-topped tube) and tubes with EDTA (Vacutainer ${ }^{\circledR}$, Franklin Lakes, NJ, USA). The blood collected with the yellow-topped tube was allowed to stand for $30 \mathrm{~min}$, centrifuged at $2000 \times \mathrm{g}$ for $10 \mathrm{~min}$, and the serum frozen at $-70^{\circ} \mathrm{C}$ for further analysis. Whole blood collected with EDTA tubes was immediately used to isolate PBMC using Histopaque ${ }^{\circledR}-1077$ (Sigma-Aldrich, St. Louis, MO, USA).

\subsection{Anthropometric and Blood Pressure Measurements}

Waist circumference was measured at the end of a normal expiration, at the superior border of the iliac crest using a nonflexible body tape (Lufkin W606PM, Sparks, MD, USA) with an accuracy of $0.1 \mathrm{~cm}$. Systolic and diastolic blood pressure were measured with an automated monitor (Omron, Healthcare, Hoffman Estates, IL, USA) on the left arm, at the heart level after at least 5 min of resting in sitting position. Two measurements were made by at least $1 \mathrm{~min}$ of difference.

\subsection{Biochemical Markers}

Serum glucose and lipid profile concentrations were performed by colorimetric and enzymatic methods (Siemens ${ }^{\circledR}$, Washington, DC, USA) using an automatic analyzer (Dimension RxL, Siemens, 
Washington, DC, USA). LDL cholesterol (LDL-c) concentration was calculated using the Friedewald formula [39].

\subsection{PON1 Arylesterase Activity}

This activity was measured in serum using phenyl acetate (SigmaAldrich, St. Louis, MO, USA) as a substrate, following the methodology described by Farrell et al. [40]. Samples were diluted 400-fold in assay buffer (50 mM Tris, $1 \mathrm{mM} \mathrm{CaCl} 2, \mathrm{pH} \mathrm{8.0)}$ and processed in duplicate in a UV-compatible half-area 96-well plate (Corning Inc., Corning, NY, USA). Then, substrate buffer ( $3 \mathrm{mM}$ phenyl acetate, $50 \mathrm{mM}$ Tris, $1 \mathrm{mM} \mathrm{CaCl}_{2}$, pH 8.0) was added to each well and the reaction was finally measured at $270 \mathrm{~nm}\left(25^{\circ} \mathrm{C}\right)$ every 20 seconds for 3 min using a microplate reader (Epoch Microplate UV/Vis Spec, Winooski, VT, USA). The results were expressed as $\mathrm{kU} / \mathrm{L}$ using the molar extinction coefficient of phenol $\left(0.00131 \mu \mathrm{M}^{-1} \mathrm{~cm}^{-1}\right)$.

\subsection{PON1 Lactonase Activity}

PON1 lactonase activity was measured in serum diluted 200 -fold in sample buffer $\left(1 \mathrm{mM} \mathrm{CaCl}_{2}\right.$, $2.5 \mathrm{mM}$ bicine, $200 \mathrm{~mm} \mathrm{NaCl}, \mathrm{pH}$ 8.3) using the method described by Millar CL et al. [41]. Each sample was added by duplicate in UV-compatible half-area 96-well plate (Corning Inc., Corning, NY, USA) and mixed with substrate buffer $(0.2 \mathrm{mM}$ m-cresol purple, $3 \mathrm{mM}$ delta-valerolactone, $\mathrm{pH}$ 8.3). Finally, the reaction was measured at $577 \mathrm{~nm}\left(25^{\circ} \mathrm{C}\right)$ every 20 seconds for 6 min using a microplate reader (Epoch Microplate UV/Vis Spec, Winooski, VT, USA). The results were obtained from a calibration curve with $0.1 \mathrm{M} \mathrm{HCl}$ and substrate buffer, in a range of $0-115 \mu \mathrm{M}$.

\subsection{Myeloperoxidase (MPO)}

Serum MPO concentration was determined through an immunoenzymatic assay (MPO human ELISA (Enzyme-Linked Immuno Sorbent Assay) Kit, Cayman Chemical, Ann Arbor, MI, USA) following the manufacturer's instructions. Briefly, standard and samples were added to a coated plate with monoclonal antibodies specific for MPO and were incubated. Horseradish Peroxidase (HRP)-labeled MPO monoclonal antibody to detect the captured MPO was added. Finally, the chromogenic substrate TMB (3,3',5,5'-Tetramethylbenzidine) was added, incubated and the reaction was stopped with an acid solution. The yellow color formed was measured at $450 \mathrm{~nm}$ using a microplate reader (Multiskan Go, Thermo Scientific, Waltham, MA, USA). The intensity of the yellow color was directly proportional to the MPO concentration.

\subsection{ApoB Precipitation}

ApoB-depleted serum was obtained by precipitation of apoB-containing lipoproteins using polyethylene glycol (PEG, Pointe Scientific, INC. Ann Arbor, MI, USA), following the manufacturer's instructions. Briefly, serum was mixed with PEG in a 1:1 ratio. After mixing 10 times by inversion, samples were incubated on ice for $20 \mathrm{~min}$ and centrifuged at $10,000 \times \mathrm{g}$ for $10 \mathrm{~min}$ at $4{ }^{\circ} \mathrm{C}$. Next, the supernatant (containing the HDL) was separated and used for the measurement of AOPP.

\subsection{Advanced Oxidation Protein Products (AOPP)}

ApoB-depleted serum was diluted in $1 \times$ Phosphate Buffered Saline-PBS in a 1:5 ratio. Then, $200 \mu \mathrm{L}$ of each diluted sample were mixed in duplicate with $10 \mu \mathrm{L}$ of $1.16 \mathrm{M}$ potassium iodide and $20 \mu \mathrm{L}$ of glacial acetic acid. The mixture was centrifuged at $4000 \mathrm{RPM}$ for $10 \mathrm{~min}$ at $4{ }^{\circ} \mathrm{C}$ and the supernatant was read in duplicate at $340 \mathrm{~nm}$ in a UV-compatible half-area 96-well plate (Corning Inc., Corning, NY, USA). Finally, the results were compared with a calibration curve with chloramine T in a range of 0 to $100 \mu \mathrm{M}$. The results were expressed in units of chloramine $\mathrm{T}$. 


\subsection{Cholesterol Efflux}

J774 macrophages (ATCC, Manassas, VA, USA) were used to measure the cholesterol efflux capacity in apoB-depleted serum obtained after both intervention periods (agraz versus placebo). Cholesterol efflux was measured using the protocol described by Millar et al. [41] Cells were cultured on 24-well plates $\left(0.7 \times 10^{5}\right.$ cells/well), with RPMI (Roswell Park Memorial Institute) media (Sigma-Aldrich, St. Louis, MO, USA), 10\% fetal bovine serum (FBS; Hyclone, Logan, UT, USA) and penicillin/streptomycin (ThermoFisher Scientific, Waltham, MA, USA) and incubated at $37{ }^{\circ} \mathrm{C}$ with $5 \% \mathrm{CO}_{2}$. After $24 \mathrm{~h}$, cells were treated with RPMI media and $1 \% \mathrm{FBS}$, and loaded with [1,2-3H(N)]-cholesterol (Perkin Elmer, Waltham, MA, USA) and CI $9764 \mathrm{mg} / \mathrm{mL}$ (2,2-dimethyl-N-(2,4,6-trimethoxyphenyl) dodecanamide) (Sigma-Aldrich, St. Louis, MO, USA) for $24 \mathrm{~h}$ in the same incubation conditions. Then, cells were treated with Cpt-cAMP $25 \mathrm{mg} / \mathrm{mL}$ (8-(4-Chlorophenylthio) adenosine 3', $5^{\prime}$-cyclic monophosphate) (Sigma-Aldrich, St. Louis, MO, USA) in RPMI media and $0.2 \%$ bovine serum albumin (BSA) and incubated for $16 \mathrm{~h}$ at $37^{\circ} \mathrm{C}$ with $5 \% \mathrm{CO}_{2}$, to promote the activation of ATP-binding cassette transporter A1 (ABCA1). After washing the cells, $2.8 \%$ of apoB-depleted serum in RPMI media with $0.2 \%$ BSA was added to the cells (in triplicate). Efflux was performed for $4 \mathrm{~h}$ at $37^{\circ} \mathrm{C}$ with $5 \% \mathrm{CO}_{2}$ followed by collection of cell media and cell lysates. Cell lysates were obtained by washing cells with $0.1 \mathrm{~N} \mathrm{NaOH}$ and collection of the supernatant. Then, cell media and cell lysates were diluted into liquid scintillation cocktail and counted on the Beckman LS 6500 Scintillation Counter. Percent of cholesterol efflux was calculated as follows:

$$
\left[\frac{3 H-\text { cholesterol radioactivity in media }}{(3 H-\text { cholesterol radioactivity in media }+3 H-\text { cholesterol radioactivity in cell lysate })}\right] * 100
$$

\subsection{Inflammatory Markers}

Serum concentration of TNF- $\alpha$, MCP-1, IL-6, IL-8, and IL-1 $\beta$ were measured using the Human cytokine magnetic panel kit (catalog number HCYTOMAG-60K-05, Millipore Corporation, Burlington, MA, USA), using Luminex $x^{M A P}{ }^{\circledR}$ technology (Millipore Corporation, Burlington, MA, USA) and following the manufacturer's instructions. For the NF- $\mathrm{kB}$ measurement, the nuclear component from the PBMC was extracted first, through a nuclear extraction kit (Abcam ab113474) according to the manufacturer's protocol. Then, the NF- $\mathrm{KB}$ transcription factor was measured using the ELISA NFKB p65 transcription factor assay kit (Abcam ab133112) according to manufacturer's instructions. Absorbances were obtained at $450 \mathrm{~nm}$.

\subsection{Statistical Analysis}

Results are described based on summary measures such as mean and standard deviation (SD). The data distribution was analyze using the normality test of Shapiro Wilk. Data without normal distribution were log-transformed. Paired samples $t$-tests were conducted to analyze differences between the agraz and placebo periods. Pearson and Spearman correlations coefficient were used. All analysis were done using SPSS version 21 for Windows (SPSS, IBM Corporation, Chicago, IL, USA). Differences were considered significant at the levels ${ }^{*} p<0.05,{ }^{* *} p<0.01,{ }^{* * *} p<0.001$.

\section{Results}

\subsection{Participant Characteristics and MetS Criteria}

Forty women ( $47.2 \pm 9.4$ years old) with MetS finished the study with an adherence above $90 \%$. In addition, there were no differences in macronutrient intake and physical activity during the whole study. Baseline MetS characteristics are shown in Table 1. The HDL-c mean for these women was $42.2 \pm 6.4 \mathrm{mg} / \mathrm{dL}$ at the beginning of the study (Table 1 ). 
Table 1. Baseline metabolic syndrome characteristics of women $(n=40)$.

\begin{tabular}{cccc}
\hline Variables & \multicolumn{3}{c}{ Mean \pm SD } \\
\hline Age (years) & 47.2 & \pm & 9.4 \\
Waist circumference $(\mathrm{cm})$ & 102 & \pm & 9.2 \\
Systolic blood pressure $(\mathrm{mm} \mathrm{Hg})$ & 118.1 & \pm & 12.5 \\
Diastolic blood pressure $(\mathrm{mm} \mathrm{Hg})$ & 76.1 & \pm & 9.3 \\
Fasting glucose $(\mathrm{mg} / \mathrm{dL})$ & 94.2 & \pm & 7.3 \\
HDL-c $(\mathrm{mg} / \mathrm{dL})$ & 42.2 & \pm & 6.4 \\
Triglycerides $(\mathrm{mg} / \mathrm{dL})$ & 220.6 & \pm & 88.9 \\
\hline
\end{tabular}

SD, standard deviation; HDL-c, high-density lipoprotein cholesterol.

\subsection{HDL Function and Related Oxidative Markers}

There were no differences in apoA-1 concentrations, PON1 activities, cholesterol efflux capacity, $\mathrm{MPO}$ concentration, $\mathrm{MPO} / \mathrm{PON} 1$ ratio and AOPP, after comparing the end of both intervention periods (placebo versus agraz) $(p>0.05$, Table 2).

Table 2. High-density lipoprotein (HDL) function markers after 4 weeks of agraz consumption, compared to placebo, in women with metabolic syndrome.

\begin{tabular}{|c|c|c|c|c|c|c|c|c|c|c|c|c|}
\hline Variables & $n$ & \multicolumn{3}{|c|}{$\begin{array}{l}\text { Placebo } \\
\text { Mean } \pm \text { SD }\end{array}$} & \multirow[t]{2}{*}{$n$} & \multicolumn{3}{|c|}{$\begin{array}{l}\text { Agraz } \\
\text { Mean } \pm \text { SD }\end{array}$} & \multicolumn{3}{|c|}{$\begin{array}{c}\Delta \text { Change } \\
\text { (Agraz-Placebo) } \\
\text { Mean } \pm \text { SD }\end{array}$} & \multirow[t]{2}{*}{$p$} \\
\hline \multicolumn{11}{|l|}{ HDL function markers } & & \\
\hline Apo A1 (mg/dL) & 34 & 127.6 & \pm & 43.1 & 29 & 132 & \pm & 49 & 3.1 & \pm & 40.8 & 0.597 \\
\hline PON1 Arylesterase Activity (kU/L) & 38 & 77.1 & \pm & 17.5 & 38 & 76.5 & \pm & 17.5 & -0.7 & \pm & 8.8 & 0.643 \\
\hline PON1 Lactonase Activity (kU/L) & 38 & 12.6 & \pm & 2.7 & 38 & 12.6 & \pm & 2.8 & 0.2 & \pm & 1.6 & 0.862 \\
\hline Cholesterol efflux (\%) & 27 & 8.2 & \pm & 3.6 & 27 & 8.7 & \pm & 3.8 & 0.5 & \pm & 2.9 & 0.324 \\
\hline \multicolumn{13}{|l|}{ HDL-related oxidative markers } \\
\hline $\mathrm{MPO}(\mathrm{ng} / \mathrm{mL})$ & 34 & 177.8 & \pm & 74.6 & 34 & 175 & \pm & 72.7 & -11.1 & \pm & 72 & 0.795 \\
\hline $\mathrm{MPO} / \mathrm{PON} 1$ arylesterase ratio & 34 & 2.7 & \pm & 1.6 & 34 & 2.6 & \pm & 1.3 & -0.1 & \pm & 1.2 & 0.770 \\
\hline MPO/PON1 lactonase ratio & 34 & 15.5 & \pm & 7.4 & 34 & 14.9 & \pm & 6.9 & -0.7 & \pm & 6.7 & 0.515 \\
\hline $\mathrm{AOPP}(\mu \mathrm{M})$ & 29 & 99.5 & \pm & 20.9 & 29 & 97.5 & \pm & 17 & -2.0 & \pm & 19.8 & 0.703 \\
\hline
\end{tabular}

SD, standard deviation; Apo, apolipoprotein; PON1, paraoxonase 1; MPO, myeloperoxidase; AOPP, advanced oxidation protein products. Paired $t$-test was used for the analysis. Significance $p<0.05$.

After agraz consumption, but not after placebo consumption, there were moderate positives correlations between cholesterol efflux capacity with PON1 arylesterase activity $(r=0.516, p=0.006)$ and lactonase activity $(r=0.597, p=0.001)$ (Figure 2). Likewise, there was a negative correlation between the changes in HDL-c and changes in AOPP $(r=-0.400 ; p=0.031)$ (Figure 3$)$, a marker of oxidative stress associated with HDL. 


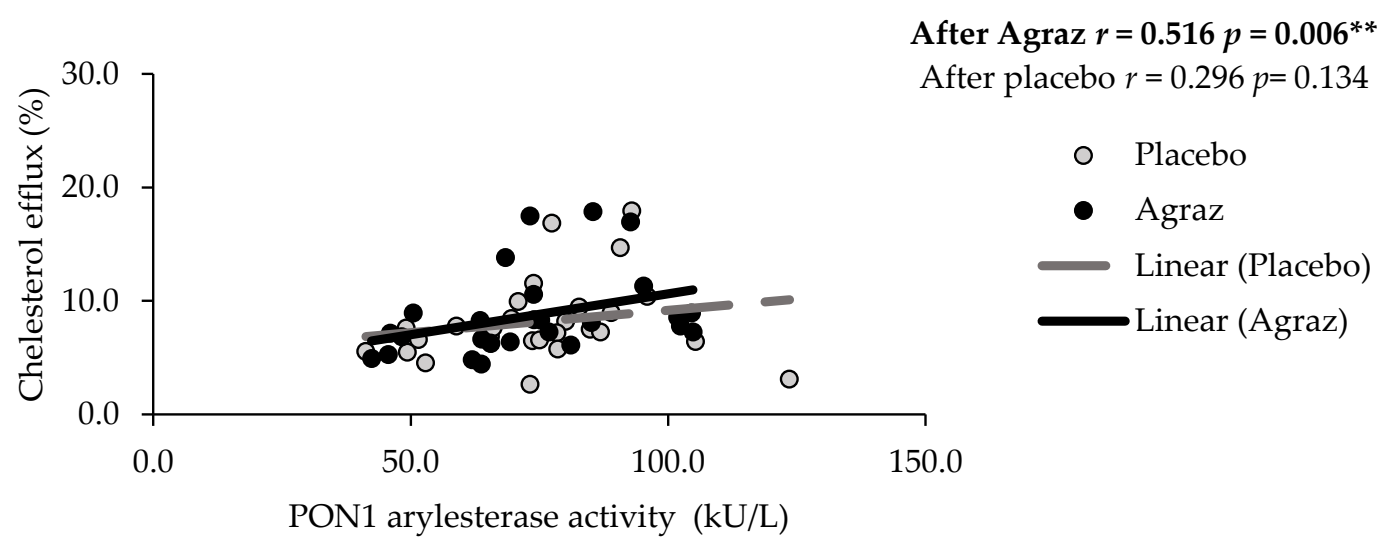

(a)

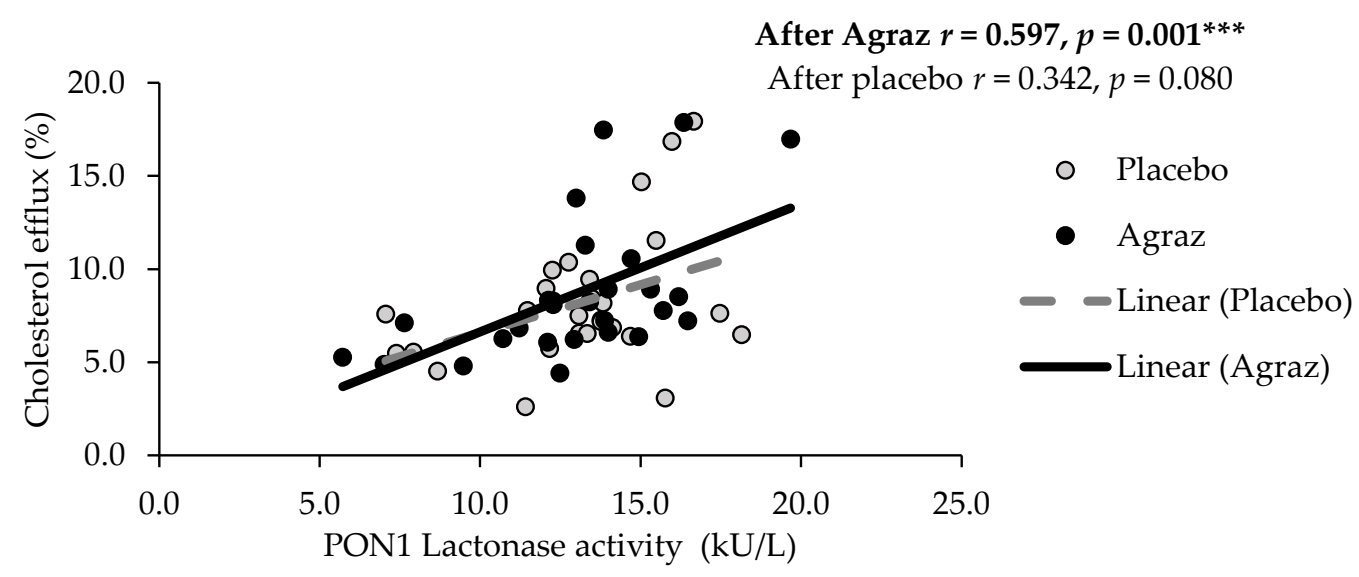

(b)

Figure 2. Spearman correlations between cholesterol efflux with (a) PON1 (paraoxonase 1) arylesterase and (b) lactonase activity after agraz consumption, compared to placebo. Significance ${ }^{*} p<0.05$, ** $p<0.01,{ }^{* * *} p<0.001$.

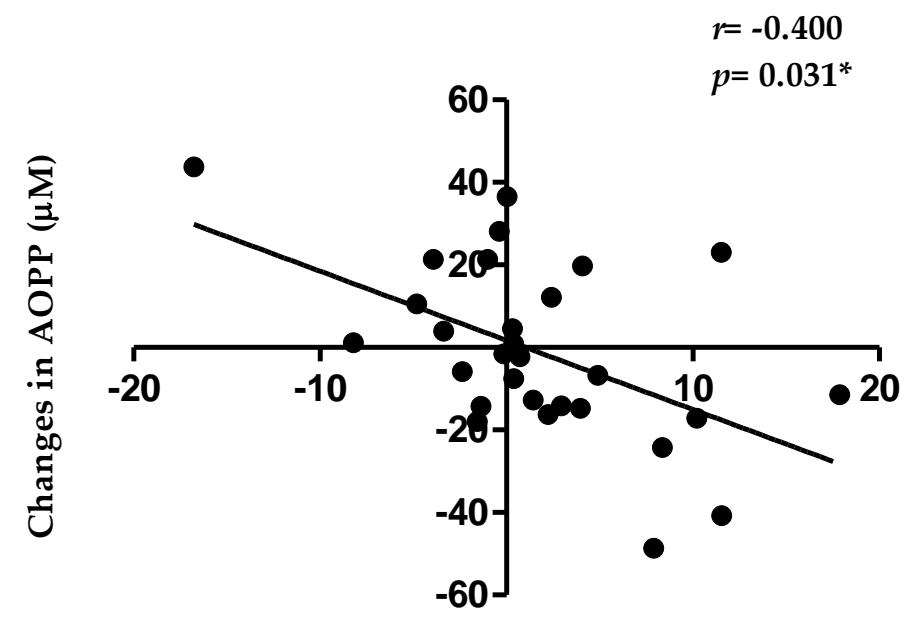

Changes in HDL-c (mg/dL)

Figure 3. Pearson correlation between changes in high-density lipoprotein cholesterol (HDL-c) and advanced oxidation protein products (AOPP) after agraz consumption, compared to placebo. Significance ${ }^{*} p<0.05$. 


\subsection{Inflammatory Markers}

There were no significant differences in inflammatory markers in this group of women after agraz consumption compared placebo (Table 3).

Table 3. Inflammation markers after 4 weeks placebo and agraz consumption.

\begin{tabular}{|c|c|c|c|c|c|c|c|c|c|c|c|c|}
\hline \multirow{2}{*}{$\begin{array}{c}\text { Variables } \\
\text { IL-1 } \beta(\mathrm{pg} / \mathrm{mL})\end{array}$} & \multirow{2}{*}{$\begin{array}{l}n \\
37\end{array}$} & \multicolumn{3}{|c|}{$\begin{array}{l}\text { Placebo } \\
\text { Mean } \pm \text { SD }\end{array}$} & \multirow{2}{*}{$\begin{array}{l}n \\
37\end{array}$} & \multicolumn{3}{|c|}{$\begin{array}{l}\text { Agraz } \\
\text { Mean } \pm \text { SD }\end{array}$} & \multicolumn{3}{|c|}{$\begin{array}{c}\Delta \text { Change } \\
\text { (Agraz-Placebo) } \\
\text { Mean } \pm \text { SD }\end{array}$} & \multirow{2}{*}{$\begin{array}{c}p \\
0.748\end{array}$} \\
\hline & & 0.8 & \pm & 0.4 & & 0.8 & \pm & 0.4 & 0.0 & \pm & 0.2 & \\
\hline IL-6 $(\mathrm{pg} / \mathrm{mL})$ & 37 & 2.6 & \pm & 2.1 & 37 & 2.1 & \pm & 1.2 & -0.5 & \pm & 1.5 & 0.271 \\
\hline IL-8 (pg/mL) & 37 & 12.6 & \pm & 5.6 & 37 & 12.1 & \pm & 5.5 & -0.3 & \pm & 2.6 & 0.322 \\
\hline $\mathrm{MCP}-1(\mathrm{pg} / \mathrm{mL})$ & 38 & 251 & \pm & 103 & 38 & 248.3 & \pm & 106.6 & -2.6 & \pm & 47.3 & 0.479 \\
\hline TNF- $\alpha(\mathrm{pg} / \mathrm{mL})$ & 38 & 4.7 & \pm & 1.8 & 38 & 4.6 & \pm & 1.5 & -0.1 & \pm & 0.8 & 0.257 \\
\hline NF-kB (abs) & 38 & 0.1 & \pm & 0.02 & 38 & 0.1 & \pm & 0.02 & 0.0 & \pm & 0.02 & 0.290 \\
\hline
\end{tabular}

SD, standard deviation; TNF- $\alpha$, tumor necrosis factor-alpha; IL, interleukin; MCP-1, monocyte chemoattractant protein-1; NF- $\mathrm{KB}$, nuclear factor kappa B. Paired $t$-test was used for the analysis. Significance $p<0.05$.

However, changes in inflammatory markers were inversely correlated with changes in PON1 activity and cholesterol efflux capacity. Moreover, changes in MPO and MPO/PON1 ratio were positively correlated with inflammatory markers (Table 4 ). Likewise, NF- $\mathrm{kB}$ levels were significantly and negatively correlated with PON1 arylesterase activity $(r=-0.431, p=0.009)$, only after placebo consumption. This correlation was not observed after agraz period (Figure 4).

Table 4. Correlations ${ }^{1}$ between changes in high-density lipoprotein (HDL) function and inflammation markers after agraz consumption, compared to placebo, in women with metabolic syndrome.

\begin{tabular}{|c|c|c|c|c|c|}
\hline Changes in Variables & $\mathrm{IL}-1 \beta(\mathrm{pg} / \mathrm{mL})$ & IL-6 (pg/mL) & IL-8 (pg/mL) & MCP-1 (pg/mL) & $\mathrm{TNF}-\alpha(\mathrm{pg} / \mathrm{mL})$ \\
\hline Apo A1 $(\mathrm{mg} / \mathrm{dL})$ & 0.151 & 0,022 & 0.056 & -0.087 & 0.030 \\
\hline PON1 Arylesterase Activity (kU/L) & 0.215 & -0.273 & -0.106 & -0.060 & -0.012 \\
\hline PON1 Lactonase Activity (kU/L) & 0.060 & $-0.390 *$ & -0.169 & 0.145 & -0.213 \\
\hline $\mathrm{MPO}(\mathrm{ng} / \mathrm{mL})$ & 0.102 & $0.707^{* * *}$ & 0.338 & $0.413 *$ & 0.196 \\
\hline $\mathrm{MPO} / \mathrm{PON} 1$ arylesterase ratio & 0.097 & $0.682^{* * *}$ & 0.349 & $0.393 *$ & 0.229 \\
\hline MPO/PON1 lactonase ratio & 0.099 & $0.701^{* * *}$ & 0.323 & 0.295 & 0.202 \\
\hline $\mathrm{AOPP}(\mu \mathrm{M})$ & 0.098 & 0.080 & -0.228 & 0.170 & -0.087 \\
\hline
\end{tabular}

${ }^{1}$ Pearson and Spearman correlation coefficients. Significance at ${ }^{*} p<0.05,{ }^{* *} p<0.01,{ }^{* * *} p<0.001$. Apo, apolipoprotein; PON1, paraoxonase 1; MPO, myeloperoxidase; AOPP, advanced oxidation protein products; TNF- $\alpha$, tumor necrosis factor-alpha; IL, interleukin; MCP-1, monocyte chemoattractant protein-1.

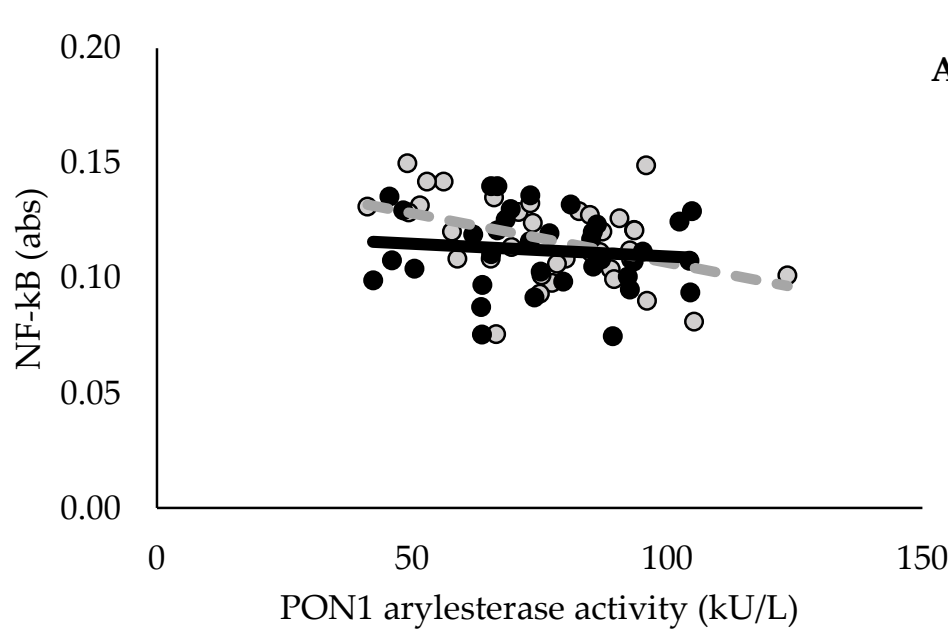

After agraz $r=-0.112, p=0.517$

After placebo $r=-0.431, p=0.009^{* *}$

- Placebo

- Agraz

$-\infty$ Linear (Placebo)

Linear (Agraz)

PON1 arylesterase activity (kU/L)

Figure 4. Pearson correlation between nuclear factor kappa B (NF-kB) and paraoxonase 1 (PON1) after agraz consumption, compared to placebo. Significance ${ }^{* *} p<0.01$. 


\section{Discussion}

The MetS is strongly linked to low-grade chronic inflammation, oxidative stress and HDL dysfunction. In this study, we evaluated the effects of consuming a fruit (agraz) rich in polyphenols (mainly anthocyanins) on these factors, which increase cardiovascular risk.

PON1 activity was measured as a HDL function marker for its atheroprotective role. Improvements in PON1 activity have been reported following the consumption of polyphenol-rich beverages like pomegranate. An increase in PON1 activity was observed following the daily consumption of a pomegranate beverage (total phenol content of $2600 \mathrm{mg}$ GAE/L of juice) for 4 weeks in 30 patients with type 2 diabetes [30]. In our study, we did not detect any significant effect on PON1 activity measures. This could be related to the lower dose provided (total phenols: $1027.97 \pm 41.99 \mathrm{mg}$ GAE/L of agraz beverage) compared to the above studies.

Cholesterol efflux capacity is another important marker that reflects the role of HDL in atheroprotection. Several studies have evaluated the effects of dietary interventions on this HDL-dependent process. For example, anthocyanin supplementation $(80 \mathrm{mg}$ of anthocyanins twice per day, Medox ${ }^{\circledR}$, Sandnes, Norway) over 24 weeks showed an increase in cholesterol efflux in macrophages cultured with the serum of hypercholesterolemic subjects ( $55.3 \pm 5.0$ years) [31]. In our study, after agraz consumption, cholesterol efflux did not change compared to placebo. Similarly, one-week intervention with $250 \mathrm{~mL}$ of polyphenol-rich beverages ( $6800 \pm 100 \mathrm{mg}$ GAE/L of juice) in 6 healthy male subjects (25-30 years), did not significantly improve cholesterol efflux rate from cells to serum, compared to serum baseline. However, cholesterol accumulation decreased significantly in macrophages cultured in the post-treatment serum. The authors of this last study concluded these results are probably due to inhibition of cholesterol-rich lipoprotein uptake by the cells, mediated by serum-associated polyphenols [42].

PON1 has been shown to stimulate HDL binding and HDL-mediated macrophage cholesterol efflux via the ABCA1 transporter [18]. We found a positive correlation between PON1 activity and cholesterol efflux after agraz consumption, but not after placebo consumption, suggesting a stronger link between these HDL markers with agraz consumption. A study with anthocyanin supplementation in subjects with hypercholesterolemia demonstrated an increased in HDL-associated PON1 activity and an improvement in cholesterol efflux capacity. This suggests that modulation of PON1 activity is a potential mechanism by which anthocyanins regulate cholesterol efflux capacity [31]. This increase in PON1 activity by polyphenols could be also associated with their capacity to modulate the expression level of the PON1 gene, acting as ligands for the aryl hydrocarbon receptor -AhR [43]; or for the peroxisome proliferator-activated receptor gamma (PPAR- $\gamma$ ) pathway [44].

MPO is able to induce HDL dysfunction through oxidative modifications, while PON1 exerts antioxidant activities on HDL $[20,21,24]$. Therefore, an increase in the MPO/PON1 ratio is considered as a potential marker of HDL dysfunction [45]. We did not observe significant changes in these parameters. However, a study in 55 healthy males evaluated the consumption of a polyphenol rich-food (cocoa extract) during 4 weeks observed that MPO was significantly reduced compared to baseline; however, no changes were found compared with the placebo group [46]. In contrast to this healthy population, our volunteers had several cardiovascular risk factors, which mediate a higher state of HDL dysfunction and oxidative stress.

Additionally, MPO is the main generator of AOPP [27]-a marker of protein oxidation which contributes to atherosclerotic plaque development- [47]. AOPP was not statistically significant between treatment periods. A study with 31 healthy subjects consuming a single dose of polyphenol-rich beverage with higher total phenol content (total polyphenols $4000 \mathrm{mg}$ GAE/L of beverage), reported that AOPP was reduced by 39\% during the first $60 \mathrm{~min}$ and tended to return to baseline within 1 and $4 \mathrm{~h}$ after consumption [48]. From this acute study, it is evident the reduction in this marker is of short duration. In our study, blood samples were taken after $12 \mathrm{~h}$ of overnight fasting. Therefore, at this time of blood sampling, any acute effect on AOPP may not have been detected. However, chronic interventions have shown positive effects in this variable. For example, after 60 days of intervention 
with $200 \mathrm{~mL}$ of cranberry juice in 56 people with MetS, AOPP decreased in relationship to the baseline values [49]. Our intervention lasted 30 days, thus, longer intervention may be necessary to obtain significant changes in this variable.

AOPP is mainly generated by MPO through $\mathrm{HOCl}$ [27]. MPO oxidizes important proteins transported by HDL, like apoA-1, producing an oxidized apoA-1 (a type of AOPP) and affecting its capacity to remove cholesterol from cells (reverse cholesterol transport) [50]. Thus, the cholesterol-enrichment of HDL is impaired and consequently the HDL-c levels are decreased. We observed a significant negative correlation between changes in AOPP and HDL-c after agraz consumption, compared to placebo. This could be associated with the inhibitory effect of some polyphenols on MPO, through direct binding of the polyphenol molecule with the active site of this enzyme [51,52], with the corresponding decrease in AOPP formation.

Inflammation is another important component of MetS [3-6]. Various studies in both healthy populations and individuals with elevated CVD risk have found anti-inflammatory effects after chronic consumption of polyphenol-rich bilberries $[53,54]$. In our study, there was no differences between agraz and placebo period. Interestingly, after agraz consumption, PON1 activity (HDL function marker) had a negative correlation with inflammatory markers as compared to placebo. PON1 activity is significantly reduced in pro-inflammatory conditions such as MetS [55], possibly due to the capacity of pro-inflammatory cytokines to inhibit PON1 expression [56]. A study with polyphenols have demonstrated anti-inflammatory effects through inhibition of NF- $\mathrm{kB}$ activation and consequent inflammatory cascade [33]. Another study showed the capacity of polyphenols to increase PON1 expression [43], as a mechanism to improve HDL function.

Similarly, we observed significant negative correlations between cholesterol efflux capacity and pro-inflammatory markers. Although this was not a study to explore mechanisms, another (in vitro) study demonstrated that anthocyanins increased ABCA1 mRNA—a cholesterol efflux regulatory protein- and consequently increased cholesterol efflux via PPAR $\alpha$ and $\operatorname{LXR} \alpha$, as well as inhibited the nuclear translocation of NF- $\mathrm{KB}$ with a reduction in pro-inflammatory protein expression [57].

\section{Conclusions}

Given that there are no previously published studies evaluating agraz consumption in people with MetS, there were no antecedents about the dose or time of intervention to be assessed with this fruit. Therefore, the daily dose used in this study was aimed to be comparable to a habitual juice consumption. The experimental design followed in this study has been employed by others evaluating polyphenol-rich fruits in people with MetS [41,58]. In conclusion, the dose of agraz used in this study during 4 weeks did not impact the HDL function, inflammatory and oxidative stress markers measured in this study, compared to placebo, in this group of women with MetS.

Author Contributions: Conceptualization and Methodology, J.B.-A., M.L.F., J.C.A., G.C.-G., V.N.-R., C.N.B., and C.M.-E.; Validation, J.B.-A., C.N.B.; Formal Analysis, C.M.-E.; Investigation, C.M.-E., Y.G.-P.; Resources, J.B.-A., C.N.B., M.L.F.; Data Curation, C.M.-E.; Writing-Original Draft Preparation, C.M.-E. and J.B.-A.; Writing-Review and Editing J.B.-A., M.L.F., C.N.B., J.C.A., G.C.-G., V.N.-R., C.M.-E., and Y.G.-P.; Visualization, C.M.-E.; Supervision, J.B.-A.; Project Administration, J.B.-A..; Funding Acquisition, J.B.-A., C.M.-E.

Funding: This study was supported by Departamento Administrativo de Ciencia, Tecnología e InnovaciónColciencias through two different grants: 111565740563, Contract No. 657-2014 and FP44842-124-2017; and the University of Antioquia UdeA, Medellin-Colombia.

Acknowledgments: We thank all the volunteers for the time and commitment dedicated to this study.

Conflicts of Interest: The authors declare no conflicts of interest. 


\section{References}

1. Alberti, K.G.M.M.; Eckel, R.H.; Grundy, S.M.; Zimmet, P.Z.; Cleeman, J.I.; Donato, K.A.; Fruchart, J.C.; James, W.P.T.; Loria, C.M.; Smith, S.C. Harmonizing the metabolic syndrome: A joint interim statement of the International Diabetes Federation Task Force on Epidemiology and Prevention; National Heart, Lung, and Blood Institute; American Heart Association; World Heart Federation; International Atherosclerosis Society; and International Association for the Study of Obesity. Circulation 2009, 120, 1640-1645.

2. WHO. Disease Burden and Mortality Estimates. Cause-Specific Mortality, 2000-2015. Global Health Estimates 2015: Estimated Deaths by Cause and Region, 2000 and 2015 (xls). Available online: http: //www.who.int/healthinfo/global_burden_disease/estimates/en/index1.html (accessed on 8 May 2018).

3. Festa, A.; D’Agostino, R.; Howard, G.; Mykkänen, L.; Tracy, R.P.; Haffner, S.M. Chronic subclinical inflammation as part of the insulin resistance syndrome: The Insulin Resistance Atherosclerosis Study (IRAS). Circulation 2000, 102, 42-47. [CrossRef]

4. Mohammadi, M.; Gozashti, M.H.; Aghadavood, M.; Mehdizadeh, M.R.; Hayatbakhsh, M.M. Clinical Significance of Serum IL-6 and TNF- $\alpha$ Levels in Patients with Metabolic Syndrome. Rep. Biochem. Mol. Biol. 2017, 6, 74-79. [PubMed]

5. Kim, S.-H.; Lee, J.-W.; Im, J.-A.; Hwang, H.-J. Monocyte chemoattractant protein-1 is related to metabolic syndrome and homocysteine in subjects without clinically significant atherosclerotic cardiovascular disease. Scand. J. Clin. Lab. Investig. 2011, 71, 1-6. [CrossRef] [PubMed]

6. Shin, M.-J.; Lee, K.H.; Chung, J.H.; Park, Y.K.; Choi, M.K.; Oh, J.; Choi, J.W.; Lee, S.-H.; Chung, N.; Kang, S.-M. Circulating IL-8 levels in heart failure patients with and without metabolic syndrome. Clin. Chim. Acta 2009, 405, 139-142. [CrossRef] [PubMed]

7. Gordon, T.; Castelli, W.P.; Hjortland, M.C.; Kannel, W.B.; Dawber, T.R. High density lipoprotein as a protective factor against coronary heart disease. The Framingham Study. Am. J. Med. 1977, 62, 707-714. [CrossRef]

8. $\quad$ van der Steeg, W.A.; Holme, I.; Boekholdt, S.M.; Larsen, M.L.; Lindahl, C.; Stroes, E.S.G.; Tikkanen, M.J.; Wareham, N.J.; Faergeman, O.; Olsson, A.G.; et al. High-Density Lipoprotein Cholesterol, High-Density Lipoprotein Particle Size, and Apolipoprotein A-I: Significance for Cardiovascular Risk. J. Am. Coll. Cardiol. 2008, 51, 634-642. [CrossRef]

9. Corsetti, J.P.; Gansevoort, R.T.; Sparks, C.E.; Dullaart, R.P.F. Inflammation reduces HDL protection against primary cardiac risk. Eur. J. Clin. Investig. 2010, 40, 483-489. [CrossRef]

10. Barter, P.J.; Caulfield, M.; Eriksson, M.; Grundy, S.M.; Kastelein, J.J.P.; Komajda, M.; Lopez-Sendon, J.; Mosca, L.; Tardif, J.-C.; Waters, D.D.; et al. Effects of Torcetrapib in Patients at High Risk for Coronary Events. N. Engl. J. Med. 2007, 357, 2109-2122. [CrossRef]

11. AIM-HIGH Investigators; Boden, W.E.; Probstfield, J.L.; Anderson, T.; Chaitman, B.R.; Desvignes-Nickens, P.; Koprowicz, K.; McBride, R.; Teo, K.; Weintraub, W. Niacin in Patients with Low HDL Cholesterol Levels Receiving Intensive Statin Therapy. N. Engl. J. Med. 2011, 365, 2255-2267.

12. Khera, A.V.; Cuchel, M.; de la Llera-Moya, M.; Rodrigues, A.; Burke, M.F.; Jafri, K.; French, B.C.; Phillips, J.A.; Mucksavage, M.L.; Wilensky, R.L.; et al. Cholesterol Efflux Capacity, High-Density Lipoprotein Function, and Atherosclerosis. N. Engl. J. Med. 2011, 364, 127-135. [CrossRef] [PubMed]

13. Van Lenten, B.J.; Hama, S.Y.; de Beer, F.C.; Stafforini, D.M.; McIntyre, T.M.; Prescott, S.M.; La Du, B.N.; Fogelman, A.M.; Navab, M. Anti-inflammatory HDL becomes pro-inflammatory during the acute phase response. Loss of protective effect of HDL against LDL oxidation in aortic wall cell cocultures. J. Clin. Investig. 1995, 96, 2758-2767. [CrossRef]

14. Kontush, A.; Chapman, M.J. Antiatherogenic function of HDL particle subpopulations: Focus on antioxidative activities. Curr. Opin. Lipidol. 2010, 21, 312-318. [CrossRef]

15. Hansel, B.; Giral, P.; Nobecourt, E.; Chantepie, S.; Bruckert, E.; Chapman, M.J.; Kontush, A. Metabolic Syndrome Is Associated with Elevated Oxidative Stress and Dysfunctional Dense High-Density Lipoprotein Particles Displaying Impaired Antioxidative Activity. J. Clin. Endocrinol. Metab. 2004, 89, 4963-4971. [CrossRef] [PubMed]

16. Annema, W.; Dikkers, A.; de Boer, J.F.; van Greevenbroek, M.M.J.; van der Kallen, C.J.H.; Schalkwijk, C.G.; Stehouwer, C.D.A.; Dullaart, R.P.F.; Tietge, U.J.F. Impaired HDL cholesterol efflux in metabolic syndrome is unrelated to glucose tolerance status: The CODAM study. Sci. Rep. 2016, 6, 27367. [CrossRef] [PubMed] 
17. de Souza, J.A.; Vindis, C.; Hansel, B.; Nègre-Salvayre, A.; Therond, P.; Serrano, C.V.; Chantepie, S.; Salvayre, R.; Bruckert, E.; Chapman, M.J.; et al. Metabolic syndrome features small, apolipoprotein A-I-poor, triglyceride-rich HDL3 particles with defective anti-apoptotic activity. Atherosclerosis 2008, 197, 84-94. [CrossRef] [PubMed]

18. Rosenblat, M.; Vaya, J.; Shih, D.; Aviram, M. Paraoxonase 1 (PON1) enhances HDL-mediated macrophage cholesterol efflux via the ABCA1 transporter in association with increased HDL binding to the cells: A possible role for lysophosphatidylcholine. Atherosclerosis 2005, 179, 69-77. [CrossRef]

19. Mukhamedova, N.; Escher, G.; D'Souza, W.; Tchoua, U.; Grant, A.; Krozowski, Z.; Bukrinsky, M.; Sviridov, D. Enhancing apolipoprotein A-I-dependent cholesterol efflux elevates cholesterol export from macrophages in vivo. J. Lipid Res. 2008, 49, 2312-2322. [CrossRef]

20. Mackness, M.I.; Arrol, S.; Durrington, P.N. Paraoxonase prevents accumulation of lipoperoxides in low-density lipoprotein. FEBS Lett. 1991, 286, 152-154. [CrossRef]

21. Hine, D.; Mackness, B.; Mackness, M. Coincubation of PON1, APO A1, and LCAT increases the time HDL is able to prevent LDL oxidation. IUBMB Life 2012, 64, 157-161. [CrossRef]

22. Aharoni, S.; Aviram, M.; Fuhrman, B. Paraoxonase 1 (PON1) reduces macrophage inflammatory responses. Atherosclerosis 2013, 228, 353-361. [CrossRef] [PubMed]

23. Hyka, N.; Dayer, J.M.; Modoux, C.; Kohno, T.; Edwards, C.K.; Roux-Lombard, P.; Burger, D. Apolipoprotein A-I inhibits the production of interleukin-1beta and tumor necrosis factor-alpha by blocking contact-mediated activation of monocytes by T lymphocytes. Blood 2001, 97, 2381-2389. [CrossRef] [PubMed]

24. Zheng, L.; Settle, M.; Brubaker, G.; Schmitt, D.; Hazen, S.L.; Smith, J.D.; Kinter, M. Localization of Nitration and Chlorination Sites on Apolipoprotein A-I Catalyzed by Myeloperoxidase in Human Atheroma and Associated Oxidative Impairment in ABCA1-dependent Cholesterol Efflux from Macrophages. J. Biol. Chem. 2005, 280, 38-47. [CrossRef] [PubMed]

25. Hazen, S.L.; Heinecke, J.W. 3-Chlorotyrosine, a specific marker of myeloperoxidase-catalyzed oxidation, is markedly elevated in low density lipoprotein isolated from human atherosclerotic intima. J. Clin. Investig. 1997, 99, 2075-2081. [CrossRef] [PubMed]

26. Velarde, G.P.; Sherazi, S.; Kraemer, D.F.; Bravo-Jaimes, K.; Butterfield, R.; Amico, T.; Steinmetz, S.D.; Guzman, M.; Martin, D.; Dodani, S.; et al. Clinical and Biochemical Markers of Cardiovascular Structure and Function in Women With the Metabolic Syndrome. Am. J. Cardiol. 2015, 116, 1705-1710. [CrossRef] [PubMed]

27. Capeillère-Blandin, C.; Gausson, V.; Descamps-Latscha, B.; Witko-Sarsat, V. Biochemical and spectrophotometric significance of advanced oxidized protein products. Biochim. Biophys. Acta BBA-Mol. Basis Dis. 2004, 1689, 91-102. [CrossRef] [PubMed]

28. Venturini, D.; Simão, A.N.C.; Dichi, I. Advanced oxidation protein products are more related to metabolic syndrome components than biomarkers of lipid peroxidation. Nutr. Res. 2015, 35, 759-765. [CrossRef]

29. Qin, Y.; Xia, M.; Ma, J.; Hao, Y.; Liu, J.; Mou, H.; Cao, L.; Ling, W. Anthocyanin supplementation improves serum LDL- and HDL-cholesterol concentrations associated with the inhibition of cholesteryl ester transfer protein in dyslipidemic subjects. Am. J. Clin. Nutr. 2009, 90, 485-492. [CrossRef]

30. Rock, W.; Rosenblat, M.; Miller-Lotan, R.; Levy, A.P.; Elias, M.; Aviram, M. Consumption of Wonderful Variety Pomegranate Juice and Extract by Diabetic Patients Increases Paraoxonase 1 Association with High-Density Lipoprotein and Stimulates Its Catalytic Activities. J. Agric. Food Chem. 2008, 56, 8704-8713. [CrossRef]

31. Zhu, Y.; Huang, X.; Zhang, Y.; Wang, Y.; Liu, Y.; Sun, R.; Xia, M. Anthocyanin supplementation improves HDL-associated paraoxonase 1 activity and enhances cholesterol efflux capacity in subjects with hypercholesterolemia. J. Clin. Endocrinol. Metab. 2014, 99, 561-569. [CrossRef]

32. Lee, S.G.; Kim, B.; Yang, Y.; Pham, T.X.; Park, Y.-K.; Manatou, J.; Koo, S.I.; Chun, O.K.; Lee, J.-Y. Berry anthocyanins suppress the expression and secretion of proinflammatory mediators in macrophages by inhibiting nuclear translocation of NF-kB independent of NRF2-mediated mechanism. J. Nutr. Biochem. 2014, 25, 404-411. [CrossRef] [PubMed]

33. Jeong, J.-W.; Lee, W.; Shin, S.; Kim, G.-Y.; Choi, B.; Choi, Y. Anthocyanins Downregulate Lipopolysaccharide-Induced Inflammatory Responses in BV2 Microglial Cells by Suppressing the NF- $\mathrm{B}$ and Akt/MAPKs Signaling Pathways. Int. J. Mol. Sci. 2013, 14, 1502-1515. [CrossRef] 
34. Garzón, G.A.; Narváez, C.E.; Riedl, K.M.; Schwartz, S.J. Chemical composition, anthocyanins, non-anthocyanin phenolics and antioxidant activity of wild bilberry (Vaccinium meridionale Swartz) from Colombia. Food Chem. 2010, 122, 980-986. [CrossRef]

35. Lopera, Y.E.; Fantinelli, J.; González Arbeláez, L.F.; Rojano, B.; Ríos, J.L.; Schinella, G.; Mosca, S. Antioxidant Activity and Cardioprotective Effect of a Nonalcoholic Extract of Vaccinium meridionale Swartz during Ischemia-Reperfusion in Rats. Evid.-Based Complement. Altern. Med. ECAM 2013, 2013, 516727. [CrossRef] [PubMed]

36. Grundy, S.M.; Cleeman, J.I.; Daniels, S.R.; Donato, K.A.; Eckel, R.H.; Franklin, B.A.; Gordon, D.J.; Krauss, R.M.; Savage, P.J.; Smith, S.C.; et al. Diagnosis and Management of the Metabolic Syndrome: An American Heart Association/National Heart, Lung, and Blood Institute Scientific Statement. Circulation 2005, 112, 2735-2752. [CrossRef]

37. Espinosa-Moncada, J.; Marín-Echeverri, C.; Galvis-Pérez, Y.; Ciro-Gómez, G.; Aristizábal-Rivera, J.C.; Blesso, C.N.; Fernandez, M.L.; Barona-Acevedo, J. Evaluation of agraz consumption on adipocytokines, inflammation and oxidative stress markers in women with metabolic syndrome. Nutrients 2018, 10, 1639. [CrossRef]

38. Álvarez Monsalve, J.M.; González Zapata, L.I. Diseño de un cuestionario de frecuencia para evaluar ingesta alimentaria en la Universidad de Antioquia, Colombia. Nutr. Hosp. 2011, 26, 1333-1344.

39. Friedewald, W.T.; Levy, R.I.; Fredrickson, D.S. Estimation of the concentration of low-density lipoprotein cholesterol in plasma, without use of the preparative ultracentrifuge. Clin. Chem. 1972, 18, 499-502. [PubMed]

40. Farrell, N.; Norris, G.; Lee, S.G.; Chun, O.K.; Blesso, C.N. Anthocyanin-rich black elderberry extract improves markers of HDL function and reduces aortic cholesterol in hyperlipidemic mice. Food Funct. 2015, 6, 1278-1287. [CrossRef] [PubMed]

41. Millar, C.L.; Duclos, Q.; Garcia, C.; Norris, G.H.; Lemos, B.S.; DiMarco, D.M.; Fernandez, M.L.; Blesso, C.N. Effects of Freeze-Dried Grape Powder on High-Density Lipoprotein Function in Adults with Metabolic Syndrome: A Randomized Controlled Pilot Study. Metab. Syndr. Relat. Disord. 2018, 16, 464-469. [CrossRef]

42. Rosenblat, M.; Volkova, N.; Attias, J.; Mahamid, R.; Aviram, M. Consumption of polyphenolic-rich beverages (mostly pomegranate and black currant juices) by healthy subjects for a short term increased serum antioxidant status, and the serum's ability to attenuate macrophage cholesterol accumulation. Food Funct. 2010, 1, 99-109. [CrossRef]

43. Gouedard, C.; Barouki, R.; Morel, Y. Dietary Polyphenols Increase Paraoxonase 1 Gene Expression by an Aryl Hydrocarbon Receptor-Dependent Mechanism. Mol. Cell. Biol. 2004, 24, 5209-5222. [CrossRef]

44. Khateeb, J.; Gantman, A.; Kreitenberg, A.J.; Aviram, M.; Fuhrman, B. Paraoxonase 1 (PON1) expression in hepatocytes is upregulated by pomegranate polyphenols: A role for PPAR- $\gamma$ pathway. Atherosclerosis 2010, 208, 119-125. [CrossRef]

45. Haraguchi, Y.; Toh, R.; Hasokawa, M.; Nakajima, H.; Honjo, T.; Otsui, K.; Mori, K.; Miyamoto-Sasaki, M.; Shinohara, M.; Nishimura, K.; et al. Serum myeloperoxidase/paraoxonase 1 ratio as potential indicator of dysfunctional high-density lipoprotein and risk stratification in coronary artery disease. Atherosclerosis 2014, 234, 288-294. [CrossRef]

46. Ibero-Baraibar, I.; Abete, I.; Navas-Carretero, S.; Massis-Zaid, A.; Martinez, J.A.; Zulet, M.A. Oxidised LDL levels decreases after the consumption of ready-to-eat meals supplemented with cocoa extract within a hypocaloric diet. Nutr. Metab. Cardiovasc. Dis. 2014, 24, 416-422. [CrossRef]

47. Gryszczyńska, B.; Formanowicz, D.; Budzyń, M.; Wanic-Kossowska, M.; Pawliczak, E.; Formanowicz, P.; Majewski, W.; Strzyżewski, K.W.; Kasprzak, M.P.; Iskra, M. Advanced Oxidation Protein Products and Carbonylated Proteins as Biomarkers of Oxidative Stress in Selected Atherosclerosis-Mediated Diseases. BioMed Res. Int. 2017, 2017, 4975264. [CrossRef]

48. Nemzer, B.V.; Rodriguez, L.C.; Hammond, L.; Disilvestro, R.; Hunter, J.M.; Pietrzkowski, Z. Acute reduction of serum 8-iso-PGF2-alpha and advanced oxidation protein products in vivo by a polyphenol-rich beverage; a pilot clinical study with phytochemical and in vitro antioxidant characterization. Nutr. J. 2011, $10,67$. [CrossRef] 
49. Simão, T.N.C.; Lozovoy, M.A.B.; Simão, A.N.C.; Oliveira, S.R.; Venturini, D.; Morimoto, H.K.; Miglioranza, L.H.S.; Dichi, I. Reduced-energy cranberry juice increases folic acid and adiponectin and reduces homocysteine and oxidative stress in patients with the metabolic syndrome. Br. J. Nutr. 2013, 110, 1885-1894. [CrossRef]

50. Bergt, C.; Pennathur, S.; Fu, X.; Byun, J.; O’Brien, K.; McDonald, T.O.; Singh, P.; Anantharamaiah, G.M.; Chait, A.; Brunzell, J.; et al. The myeloperoxidase product hypochlorous acid oxidizes HDL in the human artery wall and impairs ABCA1-dependent cholesterol transport. Proc. Natl. Acad. Sci. USA 2004, 101, 13032-13037. [CrossRef]

51. Shiba, Y.; Kinoshita, T.; Chuman, H.; Taketani, Y.; Takeda, E.; Kato, Y.; Naito, M.; Kawabata, K.; Ishisaka, A.; Terao, J.; et al. Flavonoids as Substrates and Inhibitors of Myeloperoxidase: Molecular Actions of Aglycone and Metabolites. Chem. Res. Toxicol. 2008, 21, 1600-1609. [CrossRef]

52. Lu, N.; Sui, Y.; Tian, R.; Peng, Y.-Y. Inhibitive Effects of Quercetin on Myeloperoxidase-Dependent Hypochlorous Acid Formation and Vascular Endothelial Injury. J. Agric. Food Chem. 2018, 66, 4933-4940. [CrossRef]

53. Karlsen, A.; Paur, I.; Bøhn, S.K.; Sakhi, A.K.; Borge, G.I.; Serafini, M.; Erlund, I.; Laake, P.; Tonstad, S.; Blomhoff, R. Bilberry juice modulates plasma concentration of NF- $k B$ related inflammatory markers in subjects at increased risk of CVD. Eur. J. Nutr. 2010, 49, 345-355. [CrossRef]

54. Karlsen, A.; Retterstøl, L.; Laake, P.; Paur, I.; Bøhn, S.K.; Sandvik, L.; Blomhoff, R. Anthocyanins inhibit nuclear factor-kappaB activation in monocytes and reduce plasma concentrations of pro-inflammatory mediators in healthy adults. J. Nutr. 2007, 137, 1951-1954. [CrossRef]

55. Yilmaz, H.; Sayar, N.; Yilmaz, M.; Gurkan, U.; Sesal, C.; Tosu, R.; Cakmak, N.; Erer, B.; Oz, D.; Ciloglu, F.; et al. Serum paraoxonase 1 activity in women with metabolic syndrome. Kardiol. Pol. 2010, 68, 1219-1224.

56. Han, C.Y.; Chiba, T.; Campbell, J.S.; Fausto, N.; Chaisson, M.; Orasanu, G.; Plutzky, J.; Chait, A. Reciprocal and Coordinate Regulation of Serum Amyloid A Versus Apolipoprotein A-I and Paraoxonase-1 by Inflammation in Murine Hepatocytes. Arterioscler. Thromb. Vasc. Biol. 2006, 26, 1806-1813. [CrossRef]

57. Du, C.; Shi, Y.; Ren, Y.; Wu, H.; Yao, F.; Wei, J.; Hou, Y.; Wu, M. Anthocyanins inhibit high-glucose-induced cholesterol accumulation and inflammation by activating LXR $\alpha$ pathway in HK-2 cells. Drug Des. Dev. Ther. 2015, 9, 5099-5113.

58. Barona, J.; Aristizabal, J.C.; Blesso, C.N.; Volek, J.S.; Fernandez, M.L. Grape Polyphenols Reduce Blood Pressure and Increase Flow-Mediated Vasodilation in Men with Metabolic Syndrome. J. Nutr. 2012, 142, 1626-1632. [CrossRef] 